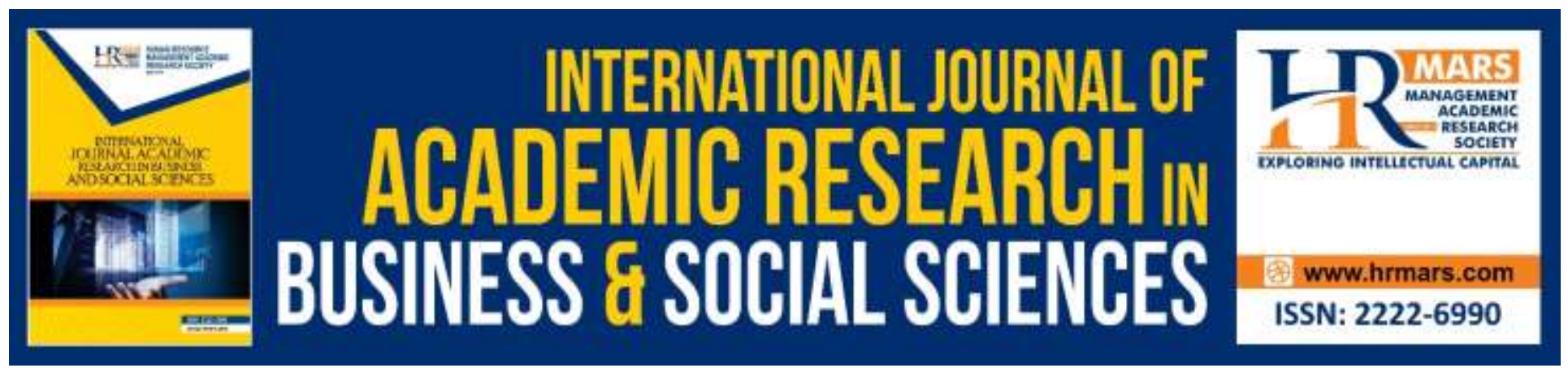

\title{
Developing Primary Students' Spoken Interaction Skill through Communicative Language Teaching
}

\author{
Aenrietta Alla Eddie, Azlina Abdul Aziz
}

To Link this Article: http://dx.doi.org/10.6007/IJARBSS/v10-i2/6931

DOI:10.6007/IJARBSS/v10-i2/6931

Received: 03 January 2020, Revised: 28 January 2020, Accepted: 02 February 2020

Published Online: 19 February 2020

In-Text Citation: (Eddie \& Aziz, 2020)

To Cite this Article: Eddie, A. A., \& Aziz, A. A. (2020). Developing Primary Students' Spoken Interaction Skill through Communicative Language Teaching. International Journal of Academic Research in Business and Social Sciences, 10(2), 303-315.

\section{Copyright: (c) 2020 The Author(s)}

Published by Human Resource Management Academic Research Society (www.hrmars.com)

This article is published under the Creative Commons Attribution (CC BY 4.0) license. Anyone may reproduce, distribute, translate and create derivative works of this article (for both commercial and non-commercial purposes), subject to full attribution to the original publication and authors. The full terms of this license may be seen

at: http://creativecommons.org/licences/by/4.0/legalcode

Vol. 10, No. 2, 2020, Pg. 303 - 315

http://hrmars.com/index.php/pages/detail/IJARBSS

JOURNAL HOMEPAGE

Full Terms \& Conditions of access and use can be found at http://hrmars.com/index.php/pages/detail/publication-ethics 


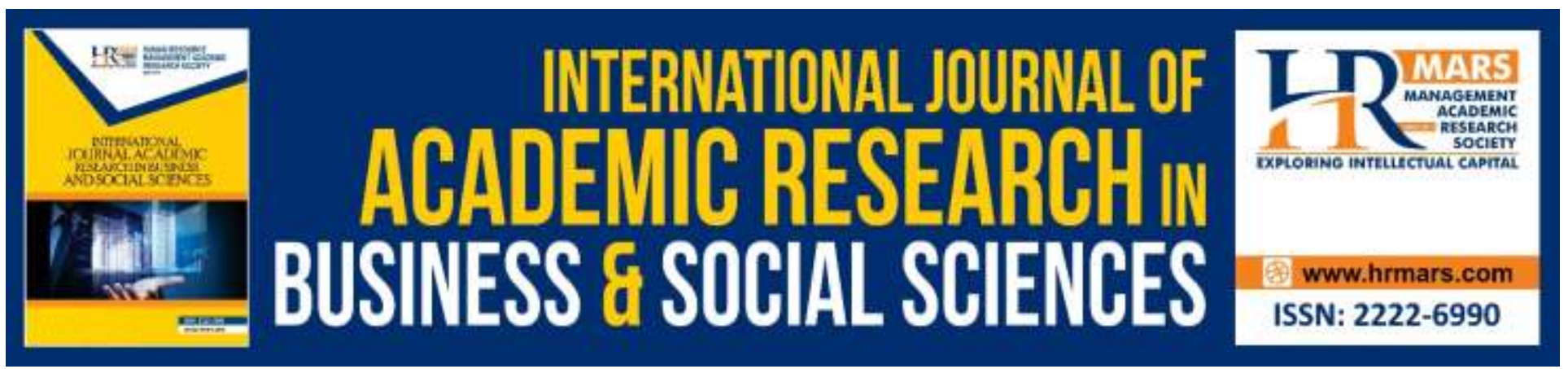

\title{
Developing Primary Students' Spoken Interaction Skill through Communicative Language Teaching
}

\author{
Aenrietta Alla Eddie ${ }^{1,2}$, Azlina Abdul Aziz ${ }^{2}$ \\ 1. SK Selepong, D/A PPD Sri Aman, 95000 Sri Aman, Sarawak, Malaysia, 2. Faculty of Education, \\ Universiti Kebangsaan Malaysia (UKM), 43600 Bangi, Selangor, Malaysia
}

\begin{abstract}
The English language is taught as early as the preschool stage and regarded as the second language in Malaysia. However, there are still students who are struggling to utter proper sentences when they reached Year 6. Thus, this action research aims to identify the effectiveness of implementing Communicative Language Teaching activities such as real-world situations role-play, peer interview, information gap filling, and other group/pair works in developing spoken interaction among primary school students. 8 low achievers of the Year 2 ESL students from a rural school in Sarawak are selected as the participants. The data is collected through pre-test and post-test, classroom observation and semi-structured interviews. The findings have shown that most of the students responded positively towards the implementation of the CLT activities and the spoken interaction in English among them has progressed significantly. Further research on this topic could include more students from other schools of various language proficiency to increase the reliability and validity of the research.
\end{abstract}

Keywords: Communicative Language Teaching, Spoken Interaction, Esl, Year 2, Rural School

\section{Research Background}

The English language curriculum in Malaysian schools has been reformed several times until the introduction of the most recent Common European Framework of Reference (CEFR) in 2017. The Malaysian Ministry of Education (MoE) has stated that this language is a mandatory subject to pass at all levels of education, emphasising the importance of being proficient in the language. One of the most fundamental English linguistic qualities to develop is spoken interaction. Spoken interaction is a productive skill in language learning. It includes communication efficiency and other essential components such as intonation, grammar, and vocabulary. These elements should be taught in every language learning to enable students to use the target language to communicate successfully. Furthermore, spoken interaction is an essential component of everyday communication, and most often, a person's first impression is painted by his or her ability to speak fluently and clearly. 
INTERNATIONAL JOURNAL OF ACADEMIC RESEARCH IN BUSINESS AND SOCIAL SCIENCES Vol. 10, No. 2, Feb, 2020, E-ISSN: 2222-6990 @ 2020 HRMARS

The capability to speak effortlessly in English would boost the employability of Malaysians. Local and foreign-based companies are progressively operating across the geographical borders, leaving it crucial to have the ability to communicate in English with national and international stakeholders. While many individuals are indeed able to use and understand English, skills such as having a sophisticated range of grammatical structures, natural pronunciation, or appropriate awareness and registration can make a great difference in how efficiently they interact in English. In the recent Job Outlook report published in January 2019, Jobstreet.com's online job portal indicated that English mastery in Malaysia appears to be a concern with 64 per cent of employers claiming a weak command of the language is the second factor behind the unemployment of fresh graduates. The Country Manager of Jobstreet.com Malaysia, Gan Bock Herm, disclosed that communication skills are among the top five necessary qualifications by recruiters, and therefore it is essential that strengthening those skills and having powerful English command would increase the likelihood of securing a position in the working world, especially for new graduates.

In this country, the problems of the oral communication skills are not new news to the public. Even though ESL was taught through kindergarten until the higher institution, there is still some major defect in the Malaysians' spoken interaction. Tunku Zain Al-'Abidin Tuanku Muhriz, the founding president of the Institute for Democracy and Economic Affairs, said that Malaysian students are still not confident enough to speak up (Bernama, 2017), based on his observations during speaking engagements at academic institutions. The purposes of the speaking lesson should, therefore, be oriented on the potentials of the students in interacting and to develop students with the willingness to express their opinions (Rusli, Yunus \& Hashim, 2018). Considering this issue, this study would focus on identifying the effectiveness of the Communicative Language Teaching (CLT) implementation in developing primary ESL students' spoken interaction skill.

CLT approach provides various communicative activities in English as a second language teaching. It is a second and foreign language teaching approach that underlined communication as both the channel and the overall purpose of language learning (Nunan, 1991). It is also labelled the "Communicative Approach". CLT has been implemented worldwide, especially in the countries in which English is not the first language. Since the earlier years, the significance of communication in the target language had been initiated. Richards (2005) indicated that expanding the potential of students to effectively communicate in the target language is a systematic process that started by encouraging them to mimic a model or react to stimuli. Thus, during the skill preparation phase, the same form of speaking exercise could be undertaken on several occasions. The activity standards in $\mathrm{CLT}$, however, should be increased to challenge the students' proficiency (Yu, 2001). In an attempt to guarantee that the attention was on meaning, task-based learning components in CLT was recommended, with an extra highlight on the assignment given to students, instead of just the language required to complete it (Nunan, 1987). In order to complement CLT classes, a range of games, role-plays, real-life scenarios and task-based discussion exercises should be arranged. Commonly, they took the shape of specific materials, such as handbooks for projects, teleprompters, activity instructions, practical aids for pair collaboration, and convenient booklets for student participation (Ellis, 2003). 
CLT has historically been viewed as a response to the Audio-Lingual Method (ALM), and as an expansion or advancement of the Notional-Functional Syllabus (Nunan, 1987). A more current refinement of CLT, known as the task-based language learning, has significantly earned popularity. However, during the 1960s, the theories driving the audiolingual approach and the teaching of situation language were widely criticised. Language theorist, Noam Chomsky (1957) dismissed the structuralist interpretation of language and stated that there is a correlation between performance and proficiency. The linguist's objective is to explore the native speakers' linguistic competence. He aptly revealed that structuralism and behaviourism could not be the ground for one major aspect of language, namely the creativity and originality of individual sentences. He also stated that imitation, repetition and routine development factors make poor arguments to compensate for any theory of language learning. Thus, this study would explore the effectiveness of the implementation of CLT activities in developing primary ESL students' spoken interaction skill.

\section{Research Objectives}

i. To identify the effectiveness of implementing CLT activities in developing spoken interaction skill among primary school students.

ii. To discover the primary students' perspectives on the implementation of CLT activities in developing their spoken interaction skill.

\section{Research Questions}

i. How does the implementation of CLT activities effective in developing spoken interaction skill among primary school students?

ii. What are the primary students' perspectives on the implementation of CLT activities in developing their spoken interaction skill?

\section{Literature Review}

\section{Spoken Interaction}

The author of the page has stated on the OpenLearn (2017) website that in spoken interaction, the language participants functioned alternately as a speaker and listener with one or more interrogators in order to form reciprocity through communicative discourse exchanges. The Council of Europe (2001) indicated that there were spoken interaction techniques for discourse and communication to organise collaboration and exchanges such as turn-taking and turn-giving, suggesting and reviewing ideas, recapturing and summarising the goal achieved, and intervening in a crisis.

\section{Past Researches on Spoken Interaction}

In a research by Tati, Paul and Golingi (2016), they revealed that the factors that were accountable for students' low ability in spoken interaction was the anxiety to speak in English. This had also included their deficiency of English language skills, competitive characteristics, limited awareness to the second language, restriction of opportunities to speak in the language, uncomfortable communicating with anyone from opposite gender, and stress from families. 
Additionally, the findings of the study had revealed that learners' apprehension of being mocked or an inclination of feeling insecure when speaking to more knowledgeable speakers, examination achievement anxiety, and the concern of being recognisable had also contributed to their spoken interaction anxiety in the English language. Miskam and Saidalvi (2019) also explored the problems of the spoken interaction anxiety of the Malaysian students in comparison to past research. They discovered that most low to moderate ESL speakers began to feel nervous if they tried to speak in the second language in front of their classmates. Thus, their opportunities of actively practicing the English language and also improving their academic achievements might be restricted because of the unpleasant classroom atmosphere.

Apart from that, the minimal use and familiarity of English language among young students were another contributing factors in unsatisfactory spoken interaction abilities in the target language (Cheng, Yunus \& Mohamad, 2016). Studying English was mandatory for all students in the Malaysian education system, but it was not mandatory for them to pass. As a result, students would not concentrate on building up and maximising their English language proficiency. In a further study by Zulkefly and Razali (2019), they argued that students were incapable of seeing the critical demand to use English as a communication platform, particularly when interacting with others who had the same native tongue since using their own language rather than using English would have been more impactful and inclusive. This was also backed by a research carried out by Mohtar, Kaur, Abdullah and Mat (2015), which indicated that any setting apart from being inside the classroom did not stimulate English to be used. Frequently, the students would communicate through their native language during recess time due to the fact that they had no supervision by the teacher.

Another aspect that associated with the distress of the ESL students' spoken interaction in the language was the embarrassment of producing mistakes. It was stated in a study conducted by Ansari (2015) that students who were fearful of harsh judgement did not accept the speech errors as a normal aspect of the learning cycle, but instead as a disruption to their reputation, and as a target of amusement either from the teacher or their friends. Further research was undertaken by Galmiche (2018) also revealed that students who experienced embarrassment when using the second language could trigger permanent withdrawal from learning the language, influence task concentration, and restrict the opportunities in the language skills absorption.

\section{CLT Implementation in Malaysia}

Communicative Language Teaching (CLT) approach provides various communicative activities in English as a second language teaching. CLT has been implemented worldwide, especially in the countries in which English is not the first language. In Malaysia, the implementation of CLT in primary schools had started since the mid 1970s (Asraf, 1996). According to Mustafa (2009), the syllabus in the 1970's onward was based on the structural situational approach and was the first common content syllabus that used a common content, method, and teaching materials that led to a common examination (Darus \& Subramaniam, 2009). Apart from that, the demands for Malaysians to be fluent in English had increased as the language was used most in international trade and commerce and also the main language in science and technology (Foo \& Ricards, 2004). It is not necessary for Malaysians to be sounding like the native speakers, however, it is important for people to understand 
INTERNATIONAL JOURNAL OF ACADEMIC RESEARCH IN BUSINESS AND SOCIAL SCIENCES

Vol. 10, No. 2, Feb, 2020, E-ISSN: 2222-6990 ¿ 2020 HRMARS

each other's English to prevent misunderstanding in the conversation due to the incomprehensibility of speeches (Rajadurai, 2010).

\section{Methodology}

For this research, a mixed-method action research design had been selected. A school in the rural area, SK Selepong, was selected as the research site as the researcher was an in-service teacher in the school. The participants of this research consisted of the researcher's own students, which were 8 Year 2 (aged 8) students of low achievers. As they were rural students, the researcher found that they had limited English vocabulary knowledge, failure to comprehend the basic structure of English sentences, and heavy first language interference. They also had low motivation to learn English as its significance was not emphasised in the rural community. Apart from that, the use of the English language at home or within the society was lacking in support and guidance. Many family members in rural districts had not practiced the English language at home and, therefore, their children had not had the chance to interact in the language beyond the classroom environment. Thus, the students had negative perceptions towards English and demonstrated anxiety to learn ESL as they were worried that their peers were going to ridicule their efforts.

After all of the consents, the researcher conducted 2 cycles of the action research and had employed the pre-test and post-test to determine the participants' development in spoken interaction. The participants were involved in the CLT spoken interaction activities during the English lessons for 2 times every week during the schooling period. The activities that had been carried out included as real-world situations role-play, peer interview, information gap filling, and other group/pair works. The pre-test was done before the implementation of the CLT activities and the post-test was done after two cycles of the action research. On the other hand, the classroom observation was done throughout the implementation of the CLT activities and also after the cycles were done. The observation was based on a checklist that would aid the researcher to see any changes in the students' spoken interaction skill. Semi-structured interviews were also done after each cycle of the research where the students would express their perception towards the implementation of the CLT activities during speaking lessons. An assessment rubric for the pre-test and post-test was followed to avoid biasness. 
INTERNATIONAL JOURNAL OF ACADEMIC RESEARCH IN BUSINESS AND SOCIAL SCIENCES Vol. 10, No. 2, Feb, 2020, E-ISSN: 2222-6990 @ 2020 HRMARS

\begin{tabular}{|c|c|c|c|c|}
\hline \multirow{2}{*}{ CRITERIA } & \multicolumn{4}{|c|}{ SCORE } \\
\hline & 1 & 2 & 3 & 4 \\
\hline Vocabulary & $\begin{array}{l}\text { Uses only basic } \\
\text { vocabulary and } \\
\text { expressions with a } \\
\text { lot of errors in } \\
\text { word choice. }\end{array}$ & $\begin{array}{l}\text { Uses limited } \\
\text { vocabulary and } \\
\text { expressions with } \\
\text { some errors in } \\
\text { word choice. }\end{array}$ & $\begin{array}{l}\text { Uses a variety of } \\
\text { vocabulary and } \\
\text { expressions with } \\
\text { some errors in } \\
\text { word choice. }\end{array}$ & $\begin{array}{l}\text { Uses a variety of } \\
\text { vocabulary and } \\
\text { expressions with } \\
\text { almost no error in } \\
\text { word choice. }\end{array}$ \\
\hline Fluency & $\begin{array}{l}\text { Hesitates too } \\
\text { often when } \\
\text { speaking which } \\
\text { often interferes } \\
\text { with } \\
\text { communication. }\end{array}$ & $\begin{array}{l}\text { Speaks with some } \\
\text { hesitation which } \\
\text { often interferes } \\
\text { with } \\
\text { communication. }\end{array}$ & $\begin{array}{l}\text { Speaks with some } \\
\text { hesitation but } \\
\text { does not interfere } \\
\text { with } \\
\text { communication. }\end{array}$ & $\begin{array}{l}\text { Speaks smoothly } \\
\text { with little } \\
\text { hesitation that } \\
\text { does not interfere } \\
\text { with } \\
\text { communication. }\end{array}$ \\
\hline Content & $\begin{array}{l}\text { Does not } \\
\text { understand the } \\
\text { topic of } \\
\text { conversation. }\end{array}$ & $\begin{array}{l}\text { Shows limited } \\
\text { understanding of } \\
\text { the topic of } \\
\text { conversation. }\end{array}$ & $\begin{array}{l}\text { Shows a good } \\
\text { understanding of } \\
\text { the topic of } \\
\text { conversation. }\end{array}$ & $\begin{array}{l}\text { Shows full } \\
\text { understanding of } \\
\text { the topic of } \\
\text { conversation and } \\
\text { able to prolong the } \\
\text { conversation. }\end{array}$ \\
\hline $\begin{array}{l}\text { Body } \\
\text { language \& } \\
\text { confidence }\end{array}$ & $\begin{array}{l}\text { No eye contact } \\
\text { and voice is } \\
\text { unclear } \\
\text { /can't be heard }\end{array}$ & $\begin{array}{l}\text { Limited eye } \\
\text { contact and voice } \\
\text { is unclear } \\
\text { /can't be heard }\end{array}$ & $\begin{array}{l}\text { Limited eye } \\
\text { contact but voice } \\
\text { is somewhat clear } \\
\text { /can be heard }\end{array}$ & $\begin{array}{l}\text { Able to make eye } \\
\text { contact and voice } \\
\text { is very clear/can } \\
\text { be heard }\end{array}$ \\
\hline $\begin{array}{l}\text { Purpose \& } \\
\text { Planning }\end{array}$ & $\begin{array}{l}\text { Takes a very long } \\
\text { time to identify } \\
\text { the purpose of } \\
\text { speaking and does } \\
\text { not respond to } \\
\text { peers in an } \\
\text { organised manner. }\end{array}$ & $\begin{array}{l}\text { Takes a few } \\
\text { seconds to identify } \\
\text { the purpose of } \\
\text { speaking and } \\
\text { respond to peers in } \\
\text { a limited organised } \\
\text { manner with a lot } \\
\text { of errors. }\end{array}$ & $\begin{array}{l}\text { Able to identify } \\
\text { the purpose of } \\
\text { speaking and } \\
\text { respond to peers } \\
\text { with an organised } \\
\text { manner with little } \\
\text { errors. }\end{array}$ & $\begin{array}{l}\text { Able to identify the } \\
\text { purpose of } \\
\text { speaking } \\
\text { immediately and } \\
\text { respond to peers } \\
\text { in an organised } \\
\text { manner with } \\
\text { almost no error. }\end{array}$ \\
\hline
\end{tabular}

Table 1: Spoken Interaction Assessment Rubric Adapted from Catalina Foothills School District's Communication Rubric Grades K-2 (2018) 
INTERNATIONAL JOURNAL OF ACADEMIC RESEARCH IN BUSINESS AND SOCIAL SCIENCES

Vol. 10, No. 2, Feb, 2020, E-ISSN: 2222-6990 ㄷ 2020 HRMARS

Findings

\begin{tabular}{|c|c|c|c|c|c|c|c|c|c|c|c|c|c|c|c|c|c|c|c|c|}
\hline \multirow[t]{2}{*}{ Participants } & \multicolumn{4}{|c|}{ Vocabulary } & \multicolumn{4}{|c|}{ Fluency } & \multicolumn{4}{|c|}{ Content } & \multicolumn{4}{|c|}{$\begin{array}{l}\text { Body language } \\
\& \text { confidence }\end{array}$} & \multicolumn{4}{|c|}{$\begin{array}{l}\text { Purpose \& } \\
\text { Planning } \\
\end{array}$} \\
\hline & 4 & 3 & 2 & 1 & 4 & 3 & 2 & 1 & 4 & 3 & 2 & 1 & 4 & 3 & 2 & 1 & 4 & 3 & 2 & 1 \\
\hline S1 & & & & / & & & & / & & & & I & & & I & & & & & I \\
\hline S2 & & & & I & & & & / & & & / & & & & I & & & & & 1 \\
\hline S3 & & & 1 & & & & & 1 & & & / & & & & / & & & & I & \\
\hline S4 & & & & 1 & & & & I & & & & 1 & & & & 1 & & & & 1 \\
\hline S5 & & & / & & & & / & & & & / & & & & / & & & & I & \\
\hline S6 & & & & / & & & & / & & & & / & & & / & & & & & / \\
\hline S7 & & & & 1 & & & & I & & & & 1 & & & I & & & & & 1 \\
\hline S8 & & & & / & & & & I & & & & I & & & & I & & & & 1 \\
\hline SUM & \multicolumn{4}{|c|}{10} & \multicolumn{4}{|c|}{9} & \multicolumn{4}{|c|}{11} & \multicolumn{4}{|c|}{12} & \multicolumn{4}{|c|}{10} \\
\hline MEAN & \multicolumn{4}{|c|}{1.25} & \multicolumn{4}{|c|}{1.13} & \multicolumn{4}{|c|}{1.38} & \multicolumn{4}{|c|}{1.50} & \multicolumn{4}{|c|}{1.25} \\
\hline
\end{tabular}

Table 2: Spoken Interaction Pre-Test Result

\begin{tabular}{|c|c|c|c|c|c|c|c|c|c|c|c|c|c|c|c|c|c|c|c|c|}
\hline \multirow[t]{2}{*}{ Participants } & \multicolumn{4}{|c|}{ Vocabulary } & \multicolumn{4}{|c|}{ Fluency } & \multicolumn{4}{|c|}{ Content } & \multicolumn{4}{|c|}{$\begin{array}{l}\text { Body language } \\
\& \text { confidence }\end{array}$} & \multicolumn{4}{|c|}{$\begin{array}{c}\text { Purpose \& } \\
\text { Planning } \\
\end{array}$} \\
\hline & 4 & 3 & 2 & 1 & 4 & 3 & 2 & 1 & 4 & 3 & 2 & 1 & 4 & 3 & 2 & 1 & 4 & 3 & 2 & 1 \\
\hline S1 & & & I & & & & & I & & & 1 & & & & 1 & & & & & 1 \\
\hline S2 & & & I & & & & I & & & & 1 & & & & 1 & & & & I & \\
\hline S3 & & & / & & & & / & & & & / & & & / & & & & & I & \\
\hline S4 & & & & I & & & & I & & & & 1 & & & & 1 & & & & 1 \\
\hline S5 & & & I & & & & I & & & I & & & & I & & & & & I & \\
\hline S6 & & & & I & & & & I & & & I & . & & & I & & & & I & \\
\hline S7 & & & & I & & & & I & & & & 1 & & & 1 & & & & & 1 \\
\hline S8 & & & & 1 & & & & I & & & & 1 & & & I & & & & & 1 \\
\hline SUM & \multicolumn{4}{|c|}{12} & \multicolumn{4}{|c|}{11} & \multicolumn{4}{|c|}{14} & \multicolumn{4}{|c|}{17} & \multicolumn{4}{|c|}{12} \\
\hline MEAN & \multicolumn{4}{|c|}{1.50} & \multicolumn{4}{|c|}{1.38} & \multicolumn{4}{|c|}{1.75} & \multicolumn{4}{|c|}{2.13} & \multicolumn{4}{|c|}{1.50} \\
\hline
\end{tabular}

Table 3: Spoken Interaction Post-test Cycle 1 Result

\begin{tabular}{|c|c|c|c|c|c|c|c|c|c|c|c|c|c|c|c|c|c|c|c|c|}
\hline \multirow{2}{*}{ Participants } & \multicolumn{4}{|c|}{ Vocabulary } & \multicolumn{4}{|c|}{ Fluency } & \multicolumn{4}{|c|}{ Content } & \multicolumn{4}{|c|}{$\begin{array}{c}\text { Body language \& } \\
\text { confidence }\end{array}$} & \multicolumn{4}{|c|}{$\begin{array}{c}\text { Purpose \& } \\
\text { Planning }\end{array}$} \\
\hline & 4 & 3 & 2 & 1 & 4 & 3 & 2 & 1 & 4 & 3 & 2 & 1 & 4 & 3 & 2 & 1 & 4 & 3 & 2 & 1 \\
\hline S1 & & 1 & & & & & 1 & & & 1 & & & 1 & & & & & 1 & & \\
\hline S2 & & 1 & & & & I & & & & I & & & I & & & & & 1 & & \\
\hline S3 & & 1 & & & & I & & & I & & & & I & & & & & 1 & & \\
\hline S4 & & & & 1 & & & & 1 & & & & 1 & & & & 1 & & & & 1 \\
\hline S5 & 1 & & & & I & & & & I & & & & 1 & & & & I & & & \\
\hline S6 & & 1 & & & & I & & & & 1 & & & & 1 & & & & 1 & & \\
\hline S7 & & & 1 & & & & 1 & & & 1 & & & & 1 & & & & & 1 & \\
\hline 58 & & 1 & & & & & 1 & & & 1 & & & & 1 & & & & 1 & & \\
\hline SUM & \multicolumn{4}{|c|}{22} & \multicolumn{4}{|c|}{20} & \multicolumn{4}{|c|}{24} & \multicolumn{4}{|c|}{26} & \multicolumn{4}{|c|}{22} \\
\hline MEAN & \multicolumn{4}{|c|}{2.75} & \multicolumn{4}{|c|}{2.50} & \multicolumn{4}{|c|}{3.0} & \multicolumn{4}{|c|}{3.25} & \multicolumn{4}{|c|}{2.75} \\
\hline
\end{tabular}

Table 4: Spoken Interaction Post-Test Cycle 2 Result 
INTERNATIONAL JOURNAL OF ACADEMIC RESEARCH IN BUSINESS AND SOCIAL SCIENCES

Vol. 10, No. 2, Feb, 2020, E-ISSN: 2222-6990 @ 2020 HRMARS

The findings in Table 3 had displayed that most of the participants were able to use most of the vocabulary that they had learned. They also managed to use social conventions phrases such as "excuse me", "may I", "can I" and "please" when they wanted to initiate a conversation. Initially, the mean score for the vocabulary section of the pre-test was 1.25. After the implementation of the CLT activities, the mean score for post-test of the same section in Cycle 2 had increased positively to 2.75.

Next, the mean score for the fluency section of the assessment had increased to 2.50 in Cycle 2 compared to the previous mean score in Cycle 1, which was 1.38. One of the participants had managed to score 4 as she was able to speak smoothly and provide quick responses during the roleplay. Some of the participants had managed to score 3 as they were sometimes appeared to be unsure of what to say back to their peers, but they would eventually provide suitable responses. Thus, it did not interfere with the context of the interaction.

The mean score for the content section of the assessment had a positive jump from 1.75 in post-test Cycle 1 to 3.0 in post-test Cycle 2. Some of the participants could fully comprehend the topic of conversation after they watched the situations in the videos. They were also able to get the gist of the topic through peer interview. They even enjoyed being in the role-play as they could prolong the interaction by asking other related questions to each other. For instance, when they talked about their ambition, the conversation would later change to their parents' occupation and other stimulating activities related to the topic.

After the intervention in Cycle 2, the mean score for the body language and confidence section of the assessment had increased to 3.25, compared to the previous mean score in Cycle 1, which was 2.13. After a lot of practices of talking with their peers in small groups, most of the participants were able to make direct eye contact with their speaking partners comfortably, and their level of voices was also clear.

The Cycle 2 mean score of purpose and planning section of the assessment had an increment by 1.25 from the mean score in the Cycle 1 post-test. One of the participants who managed to score 1 had been able to identify the purpose of the spoken interaction almost immediately and was able to organise her response appropriately. The participants who managed to score 3 were able to comprehend the purpose of the conversation but had errors in the organisation of their responses. For instance, they knew their speaking partners were asking them about what they had done during school holidays, but they had mixed up their reply with the activities that they did during schooling days such as practising for sports day.

Furthermore, from the classroom observations findings, it was found that after the implementation of CLT activities in the ESL lessons, some students had started to initiate spoken interaction with their peers. It was also apparent that students seemed more enthusiastic and less stressed when speaking in English. This was due to the fact that when they were completing the tasks, they were split into small groups or in pairs. When they could share their opinions and thoughts in small groups, they would feel more secure. Also, the activities done were engaging, as they were 
INTERNATIONAL JOURNAL OF ACADEMIC RESEARCH IN BUSINESS AND SOCIAL SCIENCES Vol. 10, No. 2, Feb, 2020, E-ISSN: 2222-6990 @ 2020 HRMARS

enjoyable kid-friendly communicative group-based activities. All were enthusiastic and appeared to be appreciating the activities. They were less reserved since their peers also had to speak English.

In the semi-structured interviews, the researcher had asked the thing that the participants had enjoyed the most about the CLT activities, and most of them had said the group tasks that they executed. They enjoyed learning with their friends as they would be less shy and help each other to complete the tasks. Also, they had stated that being in groups were enjoyable as they could practice their dialogues together without their friends making fun of them. Moreover, they were excited about what real-world situation videos they might see next or the roles that they would play in the following activities. They even suggested the videos that they wanted to watch to their teacher and suggested the characters that they wanted to play. One of them had also mentioned that being in the role-play felt like playing games and did not feel like the traditional classroom learning.

Even though most of the participants had a definite improvement in their spoken interaction skill, there was still one participant who did not excel at the same rate as his peers. Similar problems were also found in the studies by Huda and Ma'mun (2018) and Sjaifullah (2019), where they discovered the issues that were causing the speaking apprehension of the students alike were overthinking, weakness in planning, discouraging surrounding in the classroom, poor language skills, poor self-esteem, and worry about the risks of creating errors. The researcher also found that this participant was struggling with speaking anxiety and low confidence which had interfered with his spoken interaction performance. This was parallel to a study done by Miskam and Saidalvi (2019) where they had detected that most low to moderate ESL speakers began to feel nervous if they tried to speak in the second language in front of their classmates. Thus, their opportunities of actively practising the English language and also improving their academic achievements might be restricted.

\section{Discussion and Recommendation}

Based on the general findings of this research, it can be concluded that CLT does have positive impacts in in developing primary students' spoken interaction skills. In the beginning, most of the students were still low in spoken interaction proficiency. However, after implementing CLT activities, it could be acknowledged that the most of their scores in the Cycle 2 post-test are higher than the scores of the Cycle 1 post-test. The findings have corresponded positively with Mangaleswaran and Aziz's (2019) research which indicated that if executed with the cooperation of teachers and students equally according to their guidelines, CLT appeared to be a very productive approach. The students can share ideas not only in their group but also with other groups. They also would be able to ask something to and from others. Apart from that, spoken interaction promotes meaningful personal interaction and learning. The learning might be of contents, skills, attitudes or processes.

On the other hand, this study is only restricted to the exploration of the successful integration of CLT activities in a rural primary school in Sarawak to develop the spoken interaction skills of the Year 2 students. The researcher would recommend that a larger sample size would be included in the future research to obtain an even more accurate result. In addition, teachers need to monitor the interactions of students in order to distinguish the various issues that could take place. Next, in order to encourage the students to practice spoken interaction on a regular basis in ESL, the teacher 
INTERNATIONAL JOURNAL OF ACADEMIC RESEARCH IN BUSINESS AND SOCIAL SCIENCES

Vol. 10, No. 2, Feb, 2020, E-ISSN: 2222-6990 @ 2020 HRMARS

could provide activities in which they would know and understand how to use phrases and expressions independently after introducing them at the presentation stage.

\section{Conclusion}

Overall, the processes in this action research have gone smoothly. This study has shown that fun and meaningful CLT activities are effective in developing the spoken interaction skill of the low proficiency Year 2 students as well as providing them with a secure environment to practice ESL. Using CLT activities in language lessons could also expose these rural students to authentic situations that could happen in their daily lives. As the current Malaysian ESL syllabus focuses on building communication skills, CLT activities and strategies may be an effective way to introduce the young learners to spoken interaction skill in English. Studies done by Oradee (2013) and Vijayan (2016) claimed that the light and fun environment could diminish the young students' apprehension of making errors while speaking English if the communicative based activity such as role-play is carried out enjoyably and the teacher accommodates them with the platform to exercise the language.

Moreover, this study is significant due to the positive impact in developing spoken interaction skill among the Year 2 ESL students as according to Nunan (1991), the CLT approach is a practical alternative in teaching and learning second or foreign language. Its emphasis on student-centred activities such as information gap-fill, pair or group work and the use of authentic language in learning and acquisition are intended to replace traditional language teaching and stress on grammar forms. In fact, the CLT approach has gained acceptance as the solution to all language teaching problems (Littlewood 2012), mainly on communication competence.

\section{Acknowledgement}

There is no conflict of interest to disclose. This article has been completed with no external funding. The authors gratefully acknowledged Universiti Kebangsaan Malaysia for providing the platform to conduct this research.

\section{References}

Ansari, M. S. (2015). Speaking Anxiety in ESL/EFL Classrooms: A Holistic Approach and Practical Study. International Journal of Educational Investigations, 2(4), 38-46.

Asraf, R. M. (1996). The English Language Syllabus for the Year 2000 and Beyond -Lessons from the Views of Teachers. The English Teacher, 25.

Bernama. (2017). Malaysian Students Unable, Unwilling To Speak Up. Retrieved May 27, 2019, from https://www.nst.com.my/news/nation/2017/07/260832/malaysian-students-unableunwhttps://www.nst.com.my/news/nation/2017/07/260832/malaysian-students-unableunwilling-speak-ideasilling-speak-ideas

Cheng, L., Yunus, M. M., \& Mohamad, M. (2016). Issues Contributing To Low Performance Of English In A National School In Song, Sarawak. Proceedings of the ICECRS, 1(1). doi:10.21070/picecrs.v1i1.519

Chomsky, N. (1957). Syntactic structures (9th ed.). Netherlands: Mouton \& Co.

Darus, S., \& Subramaniam, K. (2009). Error analysis of the written English essays of secondary school students in Malaysia: A case study. European Journal of Social Sciences, 8(3), 483-495. 
INTERNATIONAL JOURNAL OF ACADEMIC RESEARCH IN BUSINESS AND SOCIAL SCIENCES Vol. 10, No. 2, Feb, 2020, E-ISSN: 2222-6990 @ 2020 HRMARS

Ellis, R. (2003). Task-based Language Learning and Teaching. New York, NY: Oxford University Press. Foo, B., \& Richards, C. (2004). English in Malaysia. RELC Journal, 35(2), 229-240.

Galmiche, D. (2018). The Role of Shame in Language Learning. Journal of Languages, Texts, and Society, 2, 99-129. Retrieved from https://www.nottingham.ac.uk/arts/documents/ltsjournal/issue-2/shame-in-language-learning-language-texts-society-issue-2.pdf

Huda, N. L., \& Ma'mun, N. (2018). The Anxiety of EFL Students in Presentation. Journal of English Linguistics, Literature and Education. Retrieved from http://www.journal.elitenglish.org/index.php/elite/article/view/59

Littlewood, W. (2012). Communication-oriented language teaching: Where are we now? Where do we go from here? Language Teaching, 47(3), 349-362. doi:10.1017/s0261444812000134

Mangaleswaran, S., \& Aziz, A. A. (2019). The Impact of the Implementation of CLT On Students' Speaking Skills. International Journal of Scientific and Research Publications (IJSRP), 9(4), p8814. doi:10.29322/ijsrp.9.04.2019.p8814

Miskam, N. N., \& Saidalvi, A. (2019). Investigating English Language Speaking Anxiety among Malaysian Undergraduate Learners. Asian Social Science, 15(1), 1. doi:10.5539/ass.v15n1p1

Mohtar, M. T., Kaur, C., Abdullah, N. Y., \& Mat, M. (2015). Developing the Speaking Skill among ESL Elementary Learners. The Asian Journal of English Language \& Pedagogy, 3, 161-180.

Mustafa, D. (2009). ESL or EFL? TESL or TEFL?.

Nunan, D. (1987). Communicative Language Teaching: Making it work. ELT Journal, 41(2), 136-145. doi:10.1093/elt/41.2.136

Nunan, D. (1991). Communicative Tasks and the Language Curriculum. TESOL Quarterly, 25(2), 279. doi:10.2307/3587464

Oradee, T. (2013). Developing Speaking Skills Using Three Communicative Activities (Discussion, Problem-Solving, andRole-Playing). International Journal of Social Science and Humanity, 533535. doi:10.7763/ijssh.2012.v2.164

Rajadurai, J. (2010). Speaking English And The Malay Community: The struggle for participation and the negotiation of identities. Indonesia and the Malay World, 38(111), 289-301. doi:10.1080/13639811.2010.489371

Richards, J. C. (2005). Communicative Language Teaching Today. Singapore: SEAMEO Regional Language Centre

Rusli, R., Yunus, M. M., \& Hashim, H. (2018). Low Speaking Proficiency Among The Malaysian Undergraduates: Why And How? e-Prosiding Persidangan Antarabangsa Sains Sosial dan Kemanusiaan.

Sjaifullah, A. (2019). An analysis of EFL students' anxiety factors in speaking. International research journal of engineering, IT \& scientific research, 5(3), 43-48. doi:10.21744/irjeis.v5n3.655

Tati, J. S., Paul, C., \& Golingi, L. B. (2016). English Language Speaking Anxiety Among Community College Learners: How Can It Be Overcome? PEOPLE: International Journal of Social Sciences, 2(3), 38-53. doi:10.20319/pijss.2016.23.3853

Vijayan, J. C. (2016). Developing Speaking Through Conversation and Small-Talk. Journal Of English Language And Literature (JOELL), 3(1).

Yu, L. (2001). Communicative Language Teaching in China: Progress and Resistance. TESOL Quarterly, 35(1), 194. doi:10.2307/3587868 
INTERNATIONAL JOURNAL OF ACADEMIC RESEARCH IN BUSINESS AND SOCIAL SCIENCES

Vol. 10, No. 2, Feb, 2020, E-ISSN: 2222-6990 @ 2020 HRMARS

Zulkefly, F., \& Razali, A. B. (2019). Malaysian Rural Secondary School Students' Attitudes towards Learning English as a Second Language. International Journal of Instruction, 12(1), 1141-1156. doi:10.29333/iji.2019.12173a 